\title{
Research Design Based on Fatwa Making Process: An Exploratory Study
}

\author{
Shahir Akram Hassan ${ }^{1} \&$ Wan Mohd Khairul Firdaus Wan Khairuldin ${ }^{2}$ \\ ${ }^{1}$ Centre for Islamic Development Management Studies (ISDEV), Universiti Sains Malaysia, Malaysia \\ ${ }^{2}$ Fakulti Pengajian Kontemporari Islam, Universiti Sultan Zainal Abidin, Malaysia \\ Correspondence: Shahir Akram Hassan, Centre for Islamic Development Management Studies (ISDEV), Universiti \\ Sains Malaysia, Malaysia.
}

Received: April 6, 2020

Accepted: July 22, 2020

Online Published: September 30, 2020

doi:10.5430/ijhe.v9n6p241

URL: https://doi.org/10.5430/ijhe.v9n6p241

\begin{abstract}
The Fatwa making process is a process used by an Islamic mufti (A Muslim legal expert) to issue a non-binding opinion or fatwa (judicial pronouncement in Islam) on the point of Islamic sharia law when a question is raised by a mustafti (The person who asks a mufti for a fatwa), the person who has asked for a fatwa. The mufti will issue the fatwa through four fatwa-making stages, which are al-taswir (problem description), al-takyif (adaptation), al-hukm (legal explanation) and al-ifta' (fatwa determination). This process is intended to ensure the fatwa issued is accurate and appropriate. The research design is defined as a logical action plan, and it functions as a planning framework that involves all processes holistically to achieve the objectives of the study. This study explored the appropriateness of the fatwa making process in research design, the purposes, steps, and resources of the research design based on the fatwa-making process and why it is not used to conduct Islamic-related researches. The two main objectives of the study was to identify the fatwa-making process, and to analyse the research design based on the fatwa-making process. In order to achieve these objectives, the qualitative study adopted document analysis and content analysis methods. The research found that the fatwa-making process possessed detailed steps that resembled research design and was more appropriate in conducting Islamic-related research based on the purposes, actions, and resources of research designs based on the fatwa-making process.
\end{abstract}

Keywords: research design, research, fatwa-making process, Islamic-related research

\section{Introduction}

Islamic-related research is often said to have its own exigency, especially of the objectives, resources, and research tools (Hassan, 2018, 2019; Hassan \& Alias, 2017). A component in conducting research is research design, and this is defined as a logical action plan (Yin, 2015) and serves as a planning framework that involves all processes holistically to achieve the research objective (Salleh, 2019; Zikmund, 2003). The fatwa-making process is a process used by a mufti to issue a fatwa when a mustafti raises a question. The mufti will conduct the fatwa-making process through four stages, which are al-taswir (problem description), al-takyif (adaptation), al-hukm (legal explanation) and al-ifta' (fatwa determination). These stages in the fatwa-making process are aimed to ensure the fatwa issued is accurate and appropriate. The questions are, why is this process not used for Islamic-related researches? Is it proper to construct a research design based on the fatwa-making process? What are the purposes, steps, and resources of the research design based on the fatwa-making process?

Awareness of the importance of the Islamic-based research method has begun since the 1950s, specifically through articles published in Islamic Research Circle Bulletin in Aligarh, India (Salleh, 2008: p. 139). Studies that discuss the basic concepts in Islamic-based research methodology includes studies concerning scientific method concept by Ali (2008) and Alias (2014) basic statistics concept by Alizi (2005) and Mat Nawi 2012); indicator data verification concept by Ismail (2015); observational techniques concept by Yahaya (2008); and the concept of integration of social science research by (Safi, 1998).

Despite that, even to this day, studies related to the Islamic-based research method is still in its early construction stage. Studies in the conceptual stage eventually led to the operational level. Until now, there are three Islamic-based research that has been implemented on the operational level. Operational means that the method is ready to be used in research. The operational-level studies is divide into three categories. First, study dedicated to research design by Hassan, (2014) and Wan Khairuldin, (2014). Second, the method of data collection by Hamat \& Hussin, (2008) and Hassan, (2015). Third, the method of analysing data by Hanapi (2013); Hassan (2014, 2020); Miswan (2014). 
The study has two main objectives. The first was to identify the fatwa making process, while the second was to analyse the research design based on fatwa-making process. To achieve this goal, this qualitative study uses document analysis and content analysis methods.

\section{The Purpose of A Research Design in a Study}

Yin (2015) states that research design is a logical action plan and serves as a planning framework for research that involves all processes as a whole to achieve the objective of the study. This definition is in line with Zikmund (2003) who states that research design is a specific plan for a method and procedure for collecting and analysing data, which are two other components in the research besides research design.

Research in social sciences requires a design or structure before carrying out the data-collection and analysis process. The research design is not merely a work plan, but it includes a complete work plan on what needs to be done to ensure that the study is complete and achieve the objective of the study based on planned activity and time. The function of research design is to ensure that all the information achieved is adequate to answer all research questions as clearly as possible through a systematic research plan (Creswell \& Creswell, 2017) and obtained through a comprehensive and structured approach (Kasim \& Dzakiria, 2006). According to Maxwell (2012), without a precise research design, the result or outcomes of the study are weak, and, consequently, lead to the failure in answering research questions.

Othman (2014) explains that research design is determined based on research questions as well as the problems of the study with the ultimate aim of ensuring the data analysis strategy. Creswell \& Poth (2016) state that research design is referring to the entire study conducted from identifying problems to the study of research questions and leading to data collection, data analysis, and writing the report, hence the research design is a continuous process from empirical data to the phase where the conclusion of the study is obtained.

A research design is important as a framework for explaining the relationship between one variable to another in the study (George, 2019; Osanloo \& Grant, 2016; Turner, Cardinal, \& Burton, 2017). The research methodology usually influences the research design (Bell, Bryman, \& Harley, 2018; Creswell \& Creswell, 2018; Creswell \& Poth, 2016). Typically, qualitative studies are linked to exploratory and descriptive studies. It is a research method that uses a humane approach to understanding the reality of the lives in a community (Denzin \& Lincoln, 2005). This definition can be interpreted as a qualitative study which aimed to find meaning or to evaluate something from the perspective of the individual involved in the study. Quantitative studies are those such as experimental, quasi-experimental, correlation, or review (Blalock, 2017; Hudson \& Llosa, 2015; Nardi, 2018; Waddington et al., 2017).

The research design therefore, is a research strategy that has specific objectives, considering the issues of research and objectives that are relevant to the data collection and analysis of certain data, supported by appropriate references and sources with the purpose and specific steps. In summary, a research design must have the intended course, steps, and resources.

Before exploring further on research design with fatwa-making process basis, it is best to discuss fatwa-making process first. Discussions on fatwa-making process are elaborated in the following sections.

\section{Fatwa Making Process}

Fatwa-making process is a process used by a mufti to issue a fatwa when inquired by a mustafti (Al-Asyqar, 2004:21; Hisyam Yasari, 2013:877; Jum'ah, 2008). Since this process is referring to the fatwa, which is an important instrument of legal resolution and problem-solving in Islam, a comprehensive guideline has established. According Abdul Rahman (2008); Al-Misriyyah (2016); Jum'ah (2006); and Mahmud (2009), fatwa making process is divided into four stages, which are al-taswir (problem description), al-takyif (adaptation), al-hukm (legal explanation) and al-ifta' (fatwa determination). The description of this fatwa-making process is shown in Figure 1:

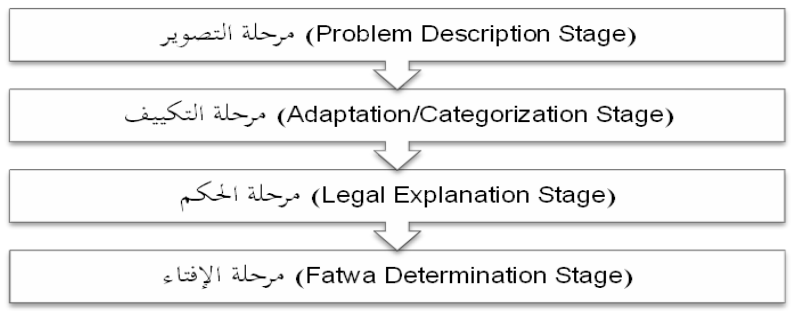

Figure 1. Stages in the fatwa-making process

Source: Jum'ah (2008); Wan et al. (2019) 
At the stage of problem description stage, every question raised by mustafti to mufti should be accurately described through various processes. This description intends to understand more precisely about the encountered problems as well as taking into account the current condition of mustafti. There are four aspects in the process of describing the problem that needs to be examined by the mufti before fatwa-making process takes place. These four aspects are the time, place, individual, and situation (Jum'ah, 2006).

The stage of adaptation (al-takyif) is best known as al-takyif al-fighi (adaptation of Islamic law). According to Ali Jum'ah (2006), al-takyif is an approach of matching the problems arising to issues which are already available in authoritative sources. This process can also be defined as a process of categorising problems into themes and fiqh discussions that corresponds to them. For example, when a banking-related question is addressed to the mufti, he will categorise the problem within the scope of the muamalah non-ibadah (acts of ritual worship, such as prayer or fasting) or will categorise the problem into a contract that has been discussed or has not been discussed by scholars. The importance of using this process is due to the mistake in determining the scope of the problem, which causes the fatwa issued to be incorrect and confusing the law of certain problems (Syabir, 2004).

The stage of legal explanation (al-hukm) begins with the gathering of information related to the evidence of the problems from the sources taken, then shifting to analysis before the fatwa is decided. Every problem enquired to the mufti is dependent on the relevant evidence from the agreed sources. If there are no agreed sources or references, then the ijtihad (independent reasoning) process should be implemented. In this process, a mufti needs to recognise the priorities of every proposition, starting from the Qur'an, al-Sunnah, consensus (al-Ijmak), analogical inference or deduction (Qiyas) (Jum'ah, 2006).

For the stage of fatwa determination (al-ifta'), after the completion of the study and the determination of the law has been conducted based on Islamic law and ijtihad (independent reasoning), the mufti needs to make the final research on the fatwa, which will be issued to the person who asked for a fatwa (mustafti) or the local community. This research examines the consistency of the fatwa with Islamic jurisprudence. In addition, the mufti should ensure the fatwa decision would not abolish the values of maqasid shariah (Shariah objectives) and not contradictory to the definitive sources $\left(Q a t^{\prime} i\right)$. If there is any contradiction with the subject matter, then the mufti needs to re-evaluate the fatwa that will be decided until the fatwa is intact and meets the Islamic code. When the research was conducted, then a fatwa can be decided or proclaimed in accordance with the national legislation (Jum'ah, 2006); (Rahman, 2008)

The fatwa-making process incorporates empirical and theoretical research methods in a specific framework. A problem studied needs to look at the original theory set by previous scholars. Then, more thorough research needs to be done by looking at various current aspects such as 'urf (custom) and affairs of the state, and laws, maqasid shariah (Shariah objectives).

\section{Fatwa Making Process as a Research Design}

There has been no specific research nor a complete procedure that has been established in the Islamic-related research methods (Salleh, 2012). However, in the tradition of Islamic science, there is some knowledge that almost resembles the design of research in conducting a study, such as in the fatwa-making process, the method of interpretation of the Qur'an and the collection of Hadith (Hassan, 2014). The knowledge in Islamic tradition is believed to be the basis for building a research design based on Islamic studies. In this regard, this paper is intended to examine the fatwa-making process in this Islamic tradition, and to explore what is appropriate from it to build a thorough, comprehensive and Islamic based research design. Based on research Wan Khairuldin (2014), in order to explore a research design based on the fatwa making process, discussions will be observed based on three important aspects in research design which are purposes, steps and resources.

The fatwa making process essentially ensures the fatwa issued is accurate and appropriate. However, challenges present in social science research that have little to do with Islamic legal aspects, such as questions related to the rate of mahr for a certain place or a family, or a discussion of current cryptocurrency laws, or specific issues concerning the legal status of products such as food and cosmetics. Research is motivated by a research problem, underpinned by objectives and questions to be answered. The fatwa making process needs to ensure that part of the research talks about the law and explains the Islamic perspective related to the issue the research explores.

Consider the use of a research design based on the fatwa-making process to carry out planned research, rather than using social science research designs such as exploratory, escriptive, or explanatory. Numerous aspects can be fulfilled such as the purpose of the study, and presenting the Islamic view of an issue. Indirectly, when a study using a fatwa research design is presented before the mufti or in a state or national fatwa conference, the mufti would not hesitate to consider the results of the research.

The design of the study based on the fatwa making process can be considered to purposively carry out research on Islamic social sciences involving all or part of the legal aspects, to be implemented using the steps and processes used 
by the mufti in answering the questions of mustafti. From the objective of this study, a research design based on fatwa-making process still meets the criteria of the existing research design, which is a specific plan for a method and procedure for collecting and analysing the data (Zikmund, 2003), based on the study of research problems (Othman, 2014) to answer all questions as clearly as possible through a systematic and logical planning (Creswell \& Creswell, 2018).

The steps of research design based on the fatwa-making through four stages mention before emphasises Islamic-based methods. This process is started with the determination of the research problem, and the assessment must be based on the major sources of Islam, which are the Qur'an and al-Sunnah to qualify for the research to proceed.

The next process in a fatwa-making research design is al-taswir (problem description), whereby researchers conduct surveys and field studies to collect data directly related to the problem. The description of the problem should be identified accurately in order to choose methods and designs appropriate in determining the results of the study. Once the problem has been identified accurately, the researcher will use the al-takyif (adaptation) process, that examines the scope and discussion of the research results. In this process, researchers can define the categories of discussions to be implemented in the process of collecting documentation data for the next process.

The next process is the al-hukm (legal explanation) process. At the beginning of this process, the researcher has identified the findings of previous studies or categories of issues discussed. Researchers need to implement two things in the process of collecting data through authoritative sources in the order of priority, and then, analyse the data. If the research is related to Islam, then the source should take precedence over such priorities in a specific order as the Qur'an, al-Sunnah, al-Ijmak, and Qiyas. Whilst in the data analysis process, data analysis methods based on usul al-fiqh such as the power of decision making of Islamic law based on existing quranic or sunnah arguments (istinbati), successive induction (istiqra 'i), recovery concept (istirdadi), and gift of God (jadali) are used to analyse the data obtained during the research.

The final process in a fatwa-making research design is al-ifta'. The al-ifta' process is used to report and present research findings after being analysed using certain methods. Before being reported, the findings of the analysis are reviewed based on the principles and maqasid shariah (the ultimate objectives of Islamic law). These reviews guarantee that the findings are accurate with Islamic law, and do not lead to harm when finalised in a research report.

Exploring the research design aspects based on fatwa-making process, it is clear that it follows a sequence of sources in the order of priorities such as the Qur'an, al-Sunnah, al-Ijmak and Qiyas, whilst the data analysis process uses data analysis methods based on the knowledge of the proof of fiqh in general, and usul al-fiqh such as istinbati (deductive), istiqra'I (inductive), istirdadi (recuperative), jadali (argumentative) and others. This sequence shows the research design based on the fatwa-making process, which emphasises Islamic sources of law commonly discussed in Islamic-related researches. It is evident that the research design based on the fatwa making process does not ignore empirical and current data. For example, at the al-takyif (adaptation) stage, there were four aspects in describing a problem that needed to be further examined by the mufti: time, place, individual, and local situation, before the fatwa-making process can take place. These are usually the factors and variables involved in social science research.

At the al-ifta' (fatwa determination) stage, the establishment of the law based on Islamic jurisprudence as well as ijtihad (independent reasoning), the mufti should consider the final research on the fatwa that will be issued to mustafti or the local community. This research examined the consistency of the fatwa within Islamic jurisprudence. Additionally, the mufti needs to ensure that the fatwa decided does not abolish the values of maqasid shariah (the ultimate objectives of Islamic law). And do not contradict the definitive sources (Qat' $i$ ). If there is any contradiction with the subject matter, then the mufti needs to re-evaluate the fatwa to ensure it is intact and meets the Islamic guidelines.

\section{Conclusion}

From the above study, the research design based on the fatwa-making process shows an orderly, meticulous procedure that can meet the requirements of conducting research, especially Islamic-related research. According to the findings from the study, at least three things can be concluded. First, the research design based on the fatwa-making process is appropriate for use in Islamic-related research, especially research involving the legal aspects of deducing law (istinbat). Secondly, the research design based on the fatwa making process has detailed research steps through four stages, namely al-taswir (problem description), al-takyif (adaptation), al-hukm (legal explanation) and $a$ l-ifta' (fatwa determination). The four stages of this process should be studied within the context of the research design as the procedure in conducting research. Thirdly, as the main Islamic sources have been compiled and recognised in the fatwa making process, the research design based on fatwa making process is more comfortable to be applied in conducting Islamic-related research and described as more holistic. It is a design based on Islamic knowledge which meets the requirements of the research design in the field of social science. 


\section{Acknowledgment}

This paper is part of the research findings entitled Research Design in Islamic-Based Research Methods [(RUI)1001/CISDEV/8016060] which was funded by Research University Individual (RUI) grant, University Sains Malaysia.

\section{References}

Abdul Rahman, N. N. (2008). al-Marahil al-Lati Tamuru Biha al-Fatawa. Al-Risalah, 8(15(1)), 100-132.

Al-Asyqar, 'Umar Sulaiman. (2004). al-Futya wa Manahij al-Ifta. Kuwait: Maktabah al-Manar al-Islamyyiah.

Al-Misriyyah, M. D. al-I. (2016). Marahil al-Fatwa. Retrieved November 2, 2019, from http://www.dar-alifta.org/Foreign/ViewFatwa.aspx?ID=7813

Ali, M. M. (2008). Conceptual and Methodological Issues in Islamic Research: A Few Milestones. Kuala Lumpur, Malaysia: Dewan Bahasa dan Pustaka (DBP).

Alias, M. S. (2014). Konsep Saintifik dalam Kaedah Penyelidikan Berteraskan Islam: Analisis Pemikiran Ibn al-Haytham. Universiti Sains Malaysia. https://doi.org/10.22452/usuluddin.vol42no1.5

Alizi, A. (2005). Social Science Research Methods and Statistics From an Islamic Perspective. In International Conference of Quantitative Sciences and Its Application, 4-15. Malaysia: Faculty of Quantitative Sciences, Universiti Utara Malaysia.

Bell, E., Bryman, A., \& Harley, B. (2018). Business research methods. Oxford university press.

Blalock, J. (2017). Causal models in the social sciences. Routledge. https://doi.org/10.4324/9781315081663

Creswell, J. W., \& Creswell, J. D. (2018). Research design: Qualitative, quantitative, and mixed methods approaches (Fifth edit). New York City, USA: SAGE Publications, Inc.

Creswell, J. W., \& Poth, C. N. (2016). Qualitative inquiry and research design: Choosing among five approaches. Sage publications.

Denzin, N. K., \& Lincoln, Y. S. (2005). Qualitative research. Denzin, NK y Lincoln YS, 2.

George, A. L. (2019). Case studies and theory development: The method of structured, focused comparison. In Alexander L. George: A Pioneer in Political and Social Sciences, 191-214. Springer. https://doi.org/10.1007/978-3-319-90772-7_10

Hamat, Z., \& Hussin, Z.-K. (2008). Kualiti Responden dalam Penyelidikan: Tinjauan awal Kes Periwayatan Hadith (Anjuran bersama Pusat Kajian Pengurusan Pembangunan Islam, Pusat Pengajian Sains Kemasyarakatan, Universiti Sains Malaysia dan Dewan Bahasa Dan Pustaka, (14). Penang, Malaysia.

Hanapi, M. S. (2013). Aplikasi Kaedah Mufassirin dalam Penganalisisan Data Penyelidikan Berkaitan Islam. In The 7th International Islamic Development Management Conference 9-10 December, 1-20. Malaysia: Centre for Islamic Development Management Studies (ISDEV).

Hassan, S. A. (2014). Aplikasi Kaedah Penaakulan Mantik Dalam Penyelidikan Berkaitan Islam. Universiti Sains Malaysia.

Hassan, S. A. (2015). Penerapan kaedah pengumpulan hadith dalam penyelidikan. Malaysia: Dewan Bahasa dan Pustaka (DBP).

Hassan, S. A. (2018). Reasoning Method: An Analysis from the Islamic Perspective. International Journal Of Academic Research In Business And Social Sciences, 8(11), 965-972. https://doi.org/10.6007/IJARBSS/v8-i11/4974

Hassan, S. A. (2019). Islamic-Based Research Methodology for Development Studies. In ICIDS 2019, September 10-12, Bandar Lampung, Indonesia, 1-10. Indonesia: EAI. https://doi.org/10.4108/eai.10-9-2019.2289396

Hassan, S. A. (2020). Penaakulan Mantik Dalam Penyelidikan (Pertama). Kuala Lumpur, Malaysia: Dewan Bahasa dan Pustaka (DBP).

Hassan, S. A., \& Alias, M. S. (2017). Strategi Penyelidikan Islam Berdasarkan Kaedah Penaakulan dalam Ilmu Mantik. Malaysian Journal For Islamic Studies, 1(2), 19-25.

Hisyam Yasari, A.-'Arabi. (2013). Manhaj al-Fatwa fi al-Qadaya al-Fiqhiyyah al-Mu,,asirah. In Mu"tamar al-Fatwa wa Istisyraf al-Mustaqbal, Jam"at al-Qasim 27-28 November 2013. Buraidah, Arab Saudi.

Hudson, T., \& Llosa, L. (2015). Design issues and inference in experimental L2 research. Language Learning, 65(S1), 76-96. https://doi.org/10.1111/lang.12113 
Ismail, N. H. (2015). Kaedah Naqd Hadith Sebagai Kaedah Penentu Kesahan Data Bagi Penyelidikan Berkaitan Islam. Universiti Sains Malaysia.

Jum'ah, M. 'Ali. (2006). Al-Kalim al-Tayyib: Fatawa "Asriyyah. Beirut: Dar al-Salam.

Jum'ah, M. 'Ali. (2008). Al-Ifta“e Haqiqatuh wa Adabuh wa Marahiluh. Mekkah, Arab Saudi.

Kasim, A., \& Dzakiria, H. (2006). Applying Qualitative Design in Research: Learning by Doing. UUM Press.

Khairuldin, W. M. K. F. W. (2014). Aplikasi proses penfatwaan dalam Kaedah Penyelidikan Berteraskan Islam. Universiti Sains Malaysia.

Mahmud, M. 'Abd al-'Aziz. (2009). Usus al-Fatwa wa Marahiluha biMafhum `Asri. Universiti Malaya, KualaLumpur.

Mat Nawi, N. I. (2012). Aplikasi Algebra Dalam Kaedah Penyelidikan Berteraskan Islam. Universiti Sains Malaysia.

Maxwell, J. A. (2012). Qualitative research design: An interactive approach ,41. Sage publications.

Miswan, M. S. (2014). Aplikasi Dilalat Dalam Kaedah Penyeylidikan Berteraskan Islam. Universiti Sains Malaysia.

Nardi, P. M. (2018). Doing survey research: A guide to quantitative methods (4th Editio). Routledge. https://doi.org/10.4324/9781315172231

Osanloo, A., \& Grant, C. (2016). Understanding, selecting, and integrating a theoretical framework in dissertation research: Creating the blueprint for your "house." Administrative Issues Journal: Connecting Education, Practice, and Research, 4(2), 7.

Othman, L. (2014). Penyelidikan Kualitatif Pengenalan Kepada Teori dan Metod. Tanjung Malim Perak: Universiti Pendidikan Sultan Idris.

Safi, L. (1998). Asas-asas Ilmu Pengetahuan. Satu Kajian Perbandingan Kaedah-kaedah Penyelidikan Islam dan Barat. (N. H. Ihsan, Ed.) (Pertama). Malaysia: Percetakan Putrajaya.

Salleh, M. S. (2008). Kaedah Penyelidikan Berteraskan Islam: Keperluan, Kedudukan dan Hala Tuju (Siri Kertas ISDEV No. 8 No. 54). Pemikir, 54. Penang, Malaysia.

Salleh, M. S. (2012). Islamic Economics Revisited: Recontemplating Unresolved Structure and Assumptions (21). Malaysia.

Salleh, M. S. (2019). Revisiting Contemporary Islamic Values. International Refereed Social Sciences Journal, 10(4), 38-42. https://doi.org/10.18843/rwjasc/v10i4/05

Syabir, M. 'Uthman. (2004). Al-Takyif al-Fiqhi li al-Waqai" al-Mustajiddat wa Tatbiqatuh al-Fiqhiyyah. Damsyik: Dar al-Qalam.

Turner, S. F., Cardinal, L. B., \& Burton, R. M. (2017). Research design for mixed methods: A triangulation-based framework and roadmap. Organizational Research Methods, 20(2), 243-267. https://doi.org/10.1177/1094428115610808

Waddington, H., Aloe, A. M., Becker, B. J., Djimeu, E. W., Hombrados, J. G., Tugwell, P., ... Reeves, B. (2017). Quasi-experimental study designs series-paper 6: risk of bias assessment. Journal of Clinical Epidemiology, 89, 43-52. https://doi.org/10.1016/j.jclinepi.2017.02.015

Wan, W. M. K. F. Bin, Embong, A. H., Hassan, S. A., Yasin, M. F. M., Anas, W. N. I. W. N., \& others. (2019). Strategic Management in Fatwa-Making Process. Academy of Strategic Management Journal.

Yahaya, F. H. (2008). Teknik Pemerhatian daripada Perspektif Islam. In Seminar Pengurusan Pembangunan Islam II Kaedah Penyelkidikan Berteraskan Islam, 1-8. Malaysia: Universiti Sains Malaysia.

Yin, R. K. (2015). Qualitative research from start to finish. Guilford Publications.

Zikmund, W. G. (2003). Business Research Methods, Mason, Ohio, South-Western. X the Restaurant Behaviour of the Berlin People.

\section{Copyrights}

Copyright for this article is retained by the author(s), with first publication rights granted to the journal.

This is an open-access article distributed under the terms and conditions of the Creative Commons Attribution license (http://creativecommons.org/licenses/by/4.0/). 